\title{
NBSIR $75-818$
}

\section{BibLIOGRAPHY OF THE ELECTROMAGNETICS DIVISION June 30,1974 to June 30,1975}

\section{Margaret L. Woolley}

(Compiler)

\section{Electromagnetics Division}

Institute for Basic Standards

National Bureau of Standards

Boulder, Colorado 80302 

NBSIR $75-818$

\section{BIBLIOGRAPHY OF THE ELECTROMAGNETICS DIVISION June 30,1974 to June 30,1975}

Margaret L. Woolley

(Compiler)

Electromagnetics Division

Institute for Basic Standards

National Bureau of Standards

Boulder, Colorado 80302

September 1975

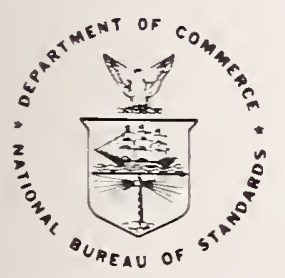

U.S. DEPARTMENT OF COMMERCE, Rogers C. B. Morton, Secretary John K. Tabor, Under Secretary

Dr. Betsy Ancker-Johnson, Assistant Secretary for Science and Technology 

INTRODUCTION. . . . . . . . . . . . . . . . . . IV IMPEDANCE . . . . . . . . . . . . . . . . . . . . I POWER AND ENERGY. . . . . . . . . . . . . . . . . . . 2 ATTENUATION . . . . . . . . . . . . . . . 5 NOISE . . . . . . . . . . . . . . . . . 6 PULSED QUANTITIES AND WAVEFORM ANALYSIS . . . . . . . 7 FIELD STRENGTH AND ANTENNA PARAMETERS . . . . . . . . 8 METHODS OF ANALYSIS . . . . . . . . . . . . . 10 AUTOMATED MEASUREMENTS. . . . . . . . . . . . . . 11 APPLICATIONS OF EM METROLOGY... . . . . . . . . . 12 LASERS. . . . . . . . . . . . . . . . . . 14 WAVEGUIDES AND TRANSMISSION LINES . . . . . . . . . . 15 EM PROPERTIES OF MATERIALS. . . . . . . . . . . . 16 ELECTROMAGNETIC INTERFERENCE. . . . . . . . . . . 17 SQUIDS AND 6-PORTS. . . . . . . . . . . . . . . 18 MISCELLANEOUS . . . . . . . . . . . . . . . . 19

AUTHOR INDEX. . . . . . . . . . . . . . . . 21 


\section{INTRODUCTION}

This bibliography lists the publications of the NBS Electromagnetics Division between June 30, 1974 and June 30, 1975. Documents accepted for publication but not yet published are also listed. All but 7 of the documents identified in the 1974 bibliography (June 30,1973 to June 30,1974 ) as "to be published" have now been published and are included in this report.

The documents in this bibliography can be categorized as follows:

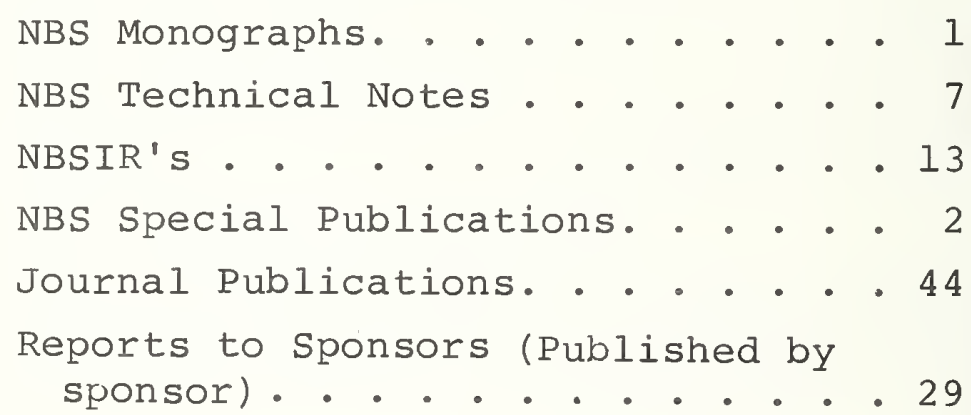




\section{IMPEDANCE}

Calculated and Measured $\mathrm{S}_{11}, \mathrm{~S}_{21}$, and Group Delay for Simple Types of Coaxial and Rectangular Waveguide 2-Port Standards Beatty, R. W.

NBS Technical Note 657

Dec. 1974,67 pages 
Laser Power and Energy Measurements

Boyne, H. S.

Proceedings SPIE Seminar on Optical Design Problems

in Laser Systems, San Diego, California

Aug. 18-22, 1975

( $T$ o be published)

Effects of Poling Conditions on Responsivity and Uniformity of Polarization of $\mathrm{PVF}_{2}$ Pyroelectric Detectors

Day, G. W., C. A. Hamilton, R. L. Peterson, R. J. Phelan,

Jr. and L. O. Mullen

Applied Physics Letters

May 1974, Vol. 23, 456

A Flat Spectral Response Detector for the Visible to

$12 \mathrm{~mm}$ region

Day, G. W., C. A. Hamilton and K. W. Pyatt

Proc. of the Infrared Information Symposia (IRIS)

Detector Specialty Meeting, March 1975,

Ft. Monmouth, N.J.

(To be published)

Performance and Characteristics of Polyvinylidene Fluoride Pyroelectric Detectors

Day, G. W., C. A. Hamilton, P. M. Gruzensky

and R. J. Phelan, Jr.

Ferroelectrics

(To be published)

Rapport sur la comparaison internationale de puissance a la frequence de $3 \mathrm{GHz}$ sur ligne coaxiale (Report on the International Comparison of Power Standards at $3 \mathrm{GHz}$ in Coaxial Line) (In French)

Engen, G. F. and P. A. Hudson

Bureau International Des Poids et Mesures

Oct. 12-13, 1972, Annexe E 17, E120-E123

A Pyroelectric Power Meter for the Measurement of Low Level Laser Radiation

Hamilton, C. A. and G. W. Day

NBS Technical Note 665

Feb. 1975, 41 pages

Electrically Calibrated Pyroelectric Radiometers Get off the Drawing Board

Hamilton, C. A., R. J. Phelan, Jr. and G. W. Day

Optical Spectra

(To be published) 
An Absolute Pyroelectric Radiometer (A Reference for Detector Responsivities)

Hamilton, C. A. and G. W. Day

Proc. of the Infrared Information Symposia (IRIS)

Detector Specialty Meeting, March ]975, Ft. Monmouth, N. J.

(To be published)

Measure Power with a Calculator Chip.....

Klein, G. P. and C. A. Hamilton

Electronic Design

oct. 11, 1974, Vol. 22, No. 21, 112-114

Analysis of Response of Pyroelectric Optical Detectors

Peterson, R. I., G. W. Day, P. M. Gruzensky and

R. J. Phelan, Jr.

Journal Applied Physics

Aug. 1974, Vol. 45, 3296

Absolute Pyroelectric Radiometers and Two Dimensional Arrays

Phelan, R. J., Jr., R. I. Peterson, G. P. Klein

C. A. Hamilton, and $G$. W. Day

Proceedings of the Electro-Optical Systems

Design Conference (New York)

Sept. 18-20, 1973, 117-123

Electrically Calibrated Pyroelectric Optical-Radiation

Detector

Phelan, R. J., Jr., and A. R. Cook

Applied Optics

oct. 1973, Vol. 12, 2494

Electrically Calibrated Detectors Versus Blackbody Sources Phelan, R. J., Jr.

Proc. of the Infrared Information Symposia (IRIS)

Detector Specialty Meeting, March 975, Et. Monmouth, N.J.

(To be published)

Radiometry without Standard Sources/Electrically

Calibrated Pyroelectrics

Phelan, R. J., Jr., C. A. Hamilton, and G. W. Day

Proceedings of the Society of Photo-Optical

Instrumentation Engineers, San Diego, California Aug. 18-22, 1975

(To be published) 
Ultrasonic Power Measurements Using Different Basic Techniques: A National Bureau of Standards-Bureau of Radiological Health Intercomparison

Stewart, H. F., R. A. Robinson, B. A. Herman, M. E. Haran,

G. R. Harris, T. L. Zapf and R. F. Metzker Journal Acoustical Soc. of America(Letter to Editor) (To be published)

Current Status of NBS Low-Power Laser Energy Measurement West, E. Dale and William E. Case

IEEE Trans. Instrumentation \& Measurement

Dec. 1974, Vol. IM-23, No. 4, 422-425

Spectral-Absorptance Measurements for Laser Calorimetry

West, E. D. and L. B. Schmidt

J. Optical Society of America

May 1975, Vol. 65, No. 5, 573-578

Calibration of Quartz Transducers As Ultrasonic Power Standards by an Electrical Method

Zapf, Thomas L.

1974 Ultrasonics Symposium Proceedings

(IEEE Cat. \#74 CHO 896-1SU)

$1974,45-50$ 
$\mathrm{RF}$ Attenuation Measurements Using Quantum Interference

in Superconductors

Adair, Robert T., Michael Bancroft Simmonds,

Robert Andrew Kamper and Cletus A. Hoer

IEEE Trans. Instrumentation \& Measurement

Dec. 1974, Vol. IM-23, No. 4, 375-381

A Rack-Mounted Precision Waveguide-Below-Cutoff Attenuator with an Absolute Electronic Readout

Cook, Clarence C.

National Bureau of Standards NBSIR 74-394

Nov. 1974, $41+i v$ pages

The Rotary Vane Attenuator as an Interlaboratory Standard Larson, Wilbur

NBS Monograph 144

(To be published) 


\section{$\underline{\text { NOISE }}$}

Frontiers of Microwave Noise Measurements at NBS Miller, C.K.S.

1975 IEEE MTT-S International Microwave Symposium Digest of Technical Papers 1975,314

A Measure for the stability of Solid state Noise Sources Kanda, Motohisa

1975 IEEE MTT-S International Microwave Symposium Digest of Technical Papers $1975,315-317$

A Statistical Measure for the stability of Solid state Noise Sources

Kanda, M.

IEEE MTT Symposium Issue

(To be published) 
Electrically Strobed Optical Waveform Sampling Oscilloscope Andrews, J. R. and R. A. Lawton

IEEE J. Quantum Electronics

(To be published)

Picosecond Pulse Generators Using Microminiature Mercury

Switches

Andrews, James R.

ivational Bureau of Standards NBSIR 74-377

Mar. 1974, $40+$ iv pages

Precision Picosecond-Pulse Measurements Using a High-Quality Superconducting Delay Line

Andrews, James $R$.

IEEE Trans. Instrumentation \& Measurement

Dec. 1974, Vol. IM-23, iNo. 4, 468-472

Pulsed Wavemeter Timing Reference for Sampling Oscilloscope

Calibration

Andrews, James R. and William L. Gans

IEEE Trans. Instrumentation \& Measurement

Mar. 1975, Vol. IM-24, No. 1, 82

Picosecond Pulse Research at INBS

Andrews, J. R. and R. A. Lawton

Joint Measurement Conference Proceedings

iNBS-Gaithersburg Nov. 12-14, 1974

(To be published)

Pulsed-Laser Application to Sampling Oscilloscope

Lawton, R. A. and J. R. Andrews

Electronics Letters

Apr. 3, 1975, Vol. 11, No. 7, 138

Optically Strobed Sampling Oscilloscope

Lawton, R. A. and J.R. Andrews

IEEE Trans. Instrumentation and Measurements

(To be published) 
Final Report on Development of Near-Field Electric Energy Density Meter Model EDM-2 for National Institute for Occupational Safety and Health

Belsher, D. R. NIOSH Report

(To be published)

Generation of Standard EM Fields Using TEM Transmission Cells

Crawford, Myron L.

IEEE Trans. Electromagnetic Compatibility

Nov. 1974, Vol. EMC-16, No. 4, 189-195

Evaluation of Reflectivity Level of Anechoic Chambers Using Isotropic 3-Dimensional Probing

Crawford, M. L.

1974 International IEEE/AP-S Symposium Digest (1974 IEEE: New York, USA)

$1974,28-34$

Generation of Standard EM Fields for Calibration of Power Density Meters $20 \mathrm{kHz}$ to $1000 \mathrm{MHz}$

Crawford, M. L.

National Bureau of Standards INBSIR 75-804

Jan. 1975, iv +40 pages

G/T Measurement Errors with Radio Stars

Daywitt, W. C. and M. Kanda

IEEE/AP-S Symposium Digest, 1975 Int'l. IEEE

AP-Symp., June 2-5, U. of Ill., Urbana, Illinois

(To be published)

Development and Construction of an Electromagnetic Near-Field Synthesizer

Greene, Frank M.

NBS Technical Note 652

May 1974, 44 pages

Development of Electric and Magnetic Near-Field Probes

Greene, Frank M.

NBS Technical iNote 658

Jan. 1975, 53 pages

Accuracy Considerations in the Measurement of the Power Gain of a Large Microwave Antenna

Kanda, M.

IEEE Trans. Antennas \& Propagation

May 1975, Vol. AP-23, INo. 3, 407-411 
Planar Near-Field Measurements on Phased Array Antennas Newell, A. C. and M. L. Crawford

1974 International IEEE/AP-S Symposium Digest 1974,423

Planar Near-Field Measurements on High Performance Array Antennas

Newell, Allen $C$. and Myron L. Crawford National Bureau of Standards NBSIR 74-380 July 1974, $93+$ vii pages

Study of Errors in Planar ivear-Field Measurements

Newell, A. C. and A. D. Yaghjian

IEEE/AP-S Symposium Digest, 1975 Int'1. IEEE

AP-Symp., June 2-5, U. of Ill., Urbana, Illinois (To be published)

Improved Polarization Measurements Using a Modified Three Antenna Technique

Newell, A. C.

IEEE/AP-S Symposium Digest, 1975 Int'l. IEEE

AP-Symp., June 2-5, U. of Ill., Urbana, Illinois

(To be published)

Antenna Measurements at the National Bureau of Standards Near-Field and Extrapolation Techniques

Wacker, Paul F.

Proc. 5th Colloquium on Microwave Communication - Vol.

5, System Measurements, Semiconductor \& Magnetic

Materials for Microwave Applications and Plasma

Phenomena (Preprints) (Akad Kiado: Budapest, Hungary) $1974, \mathrm{ME}-12 / 113-114$

Non-Planar Near-Field Measurements: Spherical Scanning Wacker, P. F. NBSIR 75-809 and A.F. Avionics Lab. Tech. Report (To be published)

Estimation of Errors in the Far-Field Quantities Determined from Measurements on a Near-Field Plane

Yaghjian, A. D.

NBS Technical Note INo. 667

(To be published) 


\section{METHODS OF ANALYSIS}

Time Domain Automatic Network Analyzer

Andrews, James R. and William L. Gans

Colloque International sur L'Electronique et

la Mesure

May $1975,259-267$

Automated Calibration of Directional-Coupler-BolometerMount Assemblies

Engen, Glenn F.

1975 IEEE MTT-S International Microwave Symposium

Digest of Technical Papers

$1975,95-97$

Exact Solution of Network Analyzer Calibration and Two-Port Measurements by sliding Terminations

Kasa, I.

1974 Conf. on Precision Electromagnetic Measurements-IEE Publication 113

July 5, 1974, 90-92

Closed-Form Mathematical Solutions to Some Network Analyzer Calibration Equations

Kasa, I.

IEEE Trans. Instrumentation \& Measurement

Dec. 1974, Vol. IM-23, No. 4, 399-402

Error Analysis of a Circle Fitting Procedure

Kasa, I.

IEEE Trans. Instrumentation \& Measurement

(To be published)

An Application of the Power Equation Concept and Automation Techniques to Precision Bolometer Unit Calibration

Komarek, Ernest L. and Peter V. Tryon

IEEE Trans. Microwave Theory \& Techniques

Dec. 1974, Vol. MTT-22, No. 12, 1260-1267 


\section{AUTOMATED MEASUREMENTS}

2-Port Standards for Evaluating Automatic Network Parameter Measurement Systems

Beatty, R. W.

1974 Conf. on Precision Electromagnetic Measurements-IEE Publication 113

July $5,1974,87-89$

Calibration Technique for Automated Network Analyzers with Application to Adapter Evaluation

Engen, Glenn F.

IEEE Trans. Microwave Theory \& Techniques

Dec. 1974, Vol. MTT-22, No. 12, 1255-1260

Alternative Calibration Technique for Automated Network Analyzers with Application to Adaptor Evaluation

Engen, G. F.

1974 IEEE S-MTT International Microwave Symposium

(IEEE Cat. No. 74CH0838 3MTT)

June $1974,261-262$ 
A Probe for Measuring Temperature in Radio Frequency Heated Material

Bowman, R. R.

Letter, IEEE MTT

(To be published)

User Guide for Courtroom Tape Recorders

Boyle, D. R. and A. R. Cook

LESL-RPT-0209.00

(To be published)

NILECJ Standard for Courtroom Audio Tape Recorders/ Reproducers

Boyle, D. R. and A. R. Cook

LESL-RPT-0216.00

(To be published)

Electromagnetic Attenuation Properties of Clay and Gravel

Soils

Ellerbruch, Doyle A.

National Bureau of Stand rds NBSIR 74-381

Aug. 1974, iv + 19 pages

Microwave Measurement of Coal Layer Thickness

Ellerbruch, Doyle A. and John W. Adams

National Bureau of Standards NBSIR 74-387

sept. 1974, $29+$ iv pages

Completion of the Program to Evaluate/Improve Instrumentation and Test Methods for Electroexplosive Device Safety Qualification

Hudson, P. A., D. G. Melquist, A. R. Ondrejka and

P. E. Werner

NBSIR 74-379 (Final Report)

June 1974,84 pages

Characterization of a High Frequency Probe Assembly for Integrated Circuit Measurements

Jesch, R. L. and C. A. Hoer

NBS Technical Note 663

Apr. 1975, 55 pages

NILECJ Standard for Batteries

Jesch, Ramon L. and Winston W. Scott, Jr.

Report to Sponsor, the Law Enforcement

Standards Laboratory

(To be published) 
FM Repeaters

Jickling, R. M. and John Shafer

NILECJ-STD-0213.00

(To be published)

Measurements of $100 \mathrm{kHz}$ Loran C Signal Strength as a Function of Vegetated Surroundings

Reeve, G. R. and J. W. Adams

Work Shop on Radio Systems in Forested and

or Vegetated Environments, US Army Communications

Command, Fort Huachuca, Arizona, Technical Report

No. $\mathrm{ACC}-\mathrm{ACO}-1-74$

Feb. 1974, I-T-i, I-T-I - I-T-7

Semiconductor Measurement Technology: Measurement of Transistor Scattering Parameters

Rogers, George J., David E. Sawyer and Ramon L. Jesch NBS Special Publication 400-5

Jan. 1975,53 pages 


\section{LASERS}

Precision Beam Splitters for $\mathrm{CO}_{2}$ Lasers

Franzen, D. L.

Applied Optics

Mar. 1975, Vol. 14, No. 3, 647-652

Laser Induced Damage in Optical Materials: 1974

Glass, Alexander J. and Arthur H. Guenther (Editors)

NBS Special Publication 414

Dec. 1974, 256 pages

A Simple Passively Mode-Locked C.W. Dye Laser

Scavennec, A. and N. S. Nahman

IEEE Journal of Quantum Electronics

Jan. 1974, Vol. QE-10, No. 1, 95-96

Active and Passive Mode Locking of Continuously Operating Rhodamine 6G Dye Lasers

Scavennec, A. and N. S. Nahman

National Bureau of Standards NBSIR 73-347

Feb. 1974,49 pages 
Inverse scattering Solutions by Least Squares

Bussey, Howard E.

1975 AP-S International Symposium (Session 7)

June 2-4, 1975, 173-174

Scattering by a Lossy Dielectric Circular Cylindrical

Multilayer Numerical Values

Bussey, H. E. and J. H. Richmond

IEEE Antennas and Propagation

(To be published)

Scattering-Matrix Description and Nearfield Measurements of Electroacoustic Transducers

Kerns, D. M.

J. Acoustical Society of America

Feb. 1975, Vol. 57, No. 2, 497-507

Direct Integration of the Field Equations for Electroacoustic Transducers

Yaghjian, A. D.

Proceedings of IEEE (Letter to Editor)

(To be published) 
International Comparison of Complex Permittivity Measurement at $9 \mathrm{GHz}$

Bussey, Howard E., Derek Morris and E. B. Zal'tsman

IEEE Trans. Instrumentation \& Measurement

Sept. 1974, Vol. IM-23, No. 3, 235-239 
Electromagnetic Noise in Grace Mine

Adams, J. W. , W. D. Bensema and M. Kanda

National Bureau of Standards NBSIR 74-388

June 1974, $127+\mathrm{x}$ pages

Surface Magnetic Field Noise Measurements at Geneva Mine

Adams, J. W., W. D. Bensema and N. C. Tomoeda

National Bureau of Standards NBSIR 74-369

June 1974, $35+$ iv pages

Electromagnetic Noise in Itmann Mine

Bensema, W. D., M. Kanda and J. W. Adams

National Bureau of Standards NBSIR 74-390

June 1974, $103+x$ pages

New Techniques for Measurement of Electromagnetic Radiation

and Susceptibility of Electronic Equipment

Crawford, M. L.

AGARD-NATO Conference in Paris, France, Oct. 21-25, 1974

(To be published in Conference Proceedings)

Electromagnetic Noise in McElroy Mine

Kanda, M. , J. W. Adams and W. D. Bensema

National Bureau of Standards NBSIR 74-389

June 1974, $156+\mathrm{xV}$ pages

Time and Amplitude Statistics for Electromagnetic Noise

in Mines

Kanda, M.

National Bureau of Standards NBSIR 74-378

Aug. 1974, 53 pages

Electromagnetic Noise in Lucky Friday Mine

Scott, W. W. J. W. Adams, W. D. Bensema and H. Dobroski

National Bureau of Standards NBSIR 74-391

Oct. $1974, \mathrm{x}+129$ pages

Broadband Pulsed/CW Calibration Signal Standard for Field Intensity Meter (FIM) Receivers

Simpson, Philip A.

National Bureau of Standards NBSIR 74-371

June 1974, 47 pages 
Using an Arbitrary Six-Port Junction to Measure Complex Voltage Ratios

Hoer, Cletus A. and Keith C. Roe

1975 IEEE MTT-S International Microwave symposium Digest of Technical Papers

$1975,98-99$

Advances in the Measurement of rf Power and Attenuation Using SQUIDS

Kamper, R. A., M. B. Simmonds, R. T. Adair and C. A. Hoer NBS Technical Note 661

Sept. 1974, 27 pages

Review of Superconducting Electronics

Kamper, Robert A.

IEEE Trans. Magnetics

Mar. 1975, Vol. MAG-11, No. 2, 141-146 


\section{MISCELLANEOUS}

United States of American Electromagnetic Standards and Calibration Facilities

Altschuler, H. M.

(To be published)

Directional Technique for Triggering a Tunnel Diode Andrews, James R.

IEEE Trans. Instrumentation \& Measurement

(To be published)

Theory of Magnetophonon structure in the Longitudinal Magnetothermal EMF

Arora, V. K. and R. L. Peterson

Physical Review B

May 1974, Vol. 9, 4323

Comment on "Who Gets Published"

Engen, Glenn

Letter to the Editor - IEEE Spectrum

(To be published)

Glossary of Standard Terms and Definitions for

Law Enforcement Communications

Jickling, R. M. and R. E. Nelson

Report to Sponsor: Law Enforcement Standards

Laboratory, NILECJ

(To be published)

Hollow-Cylinder Waveguide Isolators for Use at Millimeter Wavelengths

Kanda, Motohisa and William G. May

IEEE Trans. Microwave Theory \& Techniques

Nov. 1974, Vol. MTT-22, No. 11, 913-917

A Millimeter-Wave Reflection-Beam Isolator

Kanda, M. and W. G. May

IEEE Trans. Microwave Theory \& Techniques

June 1975, Vol. MTT-23, No. 6, 506-508

A New Millimeter Wave Isolator Containing a Semiconductor Rod in a Circular Waveguide

Kanda, M. and W. G. May

IEEE Trans. Instrumentation \& Measurement

(To be published) 
Photoconductive Detector of Fast-Transition Optical Waveforms

Lawton, R. A. and A. Scavannec

Electronics Letters

Feb. 20, 1975, Vol. 11, No. 4, 74-75

Josephson Junctions at 45 Times the Energy-Gap Frequency

McDonald, D. G., F. R. Petersen, J. D. Cupp,

B. L. Danielson and E. G. Johnson

Applied Physics Letters

Apr. 1, 1974, Vol. 24, No. 7, 335-337

Large Refractive Index Change Induced by Ion Implantation In Lithium Niobate

Wei, David T., William W. Lee and Louis R. Bloom Applied Physics Letters

Sept. 15, 1974, Vol. 25, No. 6, 329-331

Bibliography of the Electromagnetics Division - June 30, 1973 to June 30,1974

Woolley, Margaret L. (Compiler)

National Bureau of Standards NBSIR 74-395

Nov. 1974, $22+$ iv pages 
ADAIR, R. T.

5,18

ADAMS, J. W.

$12,13,17$

ALTSCHULER, H. M.

19

ANDREWS, J.R.

$7,10,19$

ARORA, V. K.

19

BEATTY, R. W.

1, 11

BELSHER, D. R.

8

BENSEMA, W. D.

17

BLOOM, L. R.

20

BOWMAN, R. R.

12

BOYLE, D. R.

12

BOYNE, H. S.

2

BUSSEY, H. E.

15,16

CASE, W. E.

4

CRAWFORD, M. L.

$$
8,9,17
$$

COOK, A. R.

3,12
COOK, C. C.

5

CUPP, J. D. 20

DANIELSON, B. L. 20

DAY, G. W. 2,3

DAYWITT, W. C. 8

DOBROWSKI, H. 17

ELLERBRUCH， D. A. 12

ENGEN, G. F . $2,10,11,19$

FRANZEN, D. L. 14

GANS, W. L. 7,10

GLASS, A. J .

14

GREENE, F. M.

8,9

GRUZENSKY, P. M.

2,3

GUENTHER, A. H.

14

HARAN, M. E.

4

HAMILTON, C. A.

2,3 
Author Index (cont.)

HARRIS, G. R. 4

HERMAN, B. A. 4 HOER, C. A.

$$
5,12,18
$$

HUDSON, P. A.

2

JESCH, R. L .

12,13

JICKLING, R. M.

13,19

JOHNSON, E. G.

20

KAMPER, R. A .

5,18

KANDA, M.

$6,8,17,19$

KASA, I.

10

KERNS, D. M.

15

KLEIN, G. P.

3

KOMAREK, E. L.

10

LARSON, W.

5

LAWTON, R. A.

7,20

LEE, $W . W$.

20
MCDONALD, D. G :

20

MAY, W. G.

19

METZGER， R. F .

4

MILLER, C. K. S.

6

MORRIS, D.

16

MULLEN, L. O.

2

NAHMAN, N. S.

14

NELSON, R. E.

19

NEWELL, A. C. 9

PETERSEN, F. R.

19

PETERSON, R. L.

2, 3， 19

PHELAN, R. J., JR.

2,3

PYATT, K. W.

2

REEVE, G. R.

13

RICHMOND, J. H.

15

ROBINSON, R. A.

4 
$R O E, K$. C.

18

ROGERS, G. J .

13

SAWYER, D. E .

13

SCAVANNEC, A.

14,20

SCHMIDT, L. B.

4

SCOTT, W. W., JR.

12,17

SHAFER， J. R.

13

SIMMONDS, M. B.

5,18

SIMPSON, P. A.

17

STEWART, H. F .

4

TOMOEDA, N. C.

17

TRYON, P. V.

10

WACKER, P. F .

9

WEI, D. T.

20

WEST, E. D.

4

WOOLLEY, M. L.

20
YAGHJIAN, A. D.

$$
9,15
$$

ZALT'SMAN, E. B.

16

ZAPF, T. I.

4 
NBS-114A (REV. 7.73)

\begin{tabular}{|c|c|c|c|}
\hline $\begin{array}{l}\text { U.S. OEPT. OF COMM. } \\
\text { BIBLIOGRAPHIC DATA } \\
\text { SHEET }\end{array}$ & $\begin{array}{l}\text { 1. PUBLICATION OR REPORT NO. } \\
\text { INESIR 75-818 }\end{array}$ & $\begin{array}{l}\text { 2. Gov't Accession } \\
\text { No. }\end{array}$ & 3. Recipient's Accession No. \\
\hline \multirow{3}{*}{\multicolumn{3}{|c|}{$\begin{array}{l}\text { 4. TITLE AND SUBTITLE } \\
\text { Bibliography of the Electramagnetics Division } \\
\text { June } 30,1974 \text { to June } 30,1975\end{array}$}} & 5. Publication Date \\
\hline & & & September 1975 \\
\hline & & & 6. Performing Organization Code \\
\hline \multicolumn{3}{|c|}{$\begin{array}{l}\text { 7. AUTHOR(S) } \\
\text { Mlargaret L. IVoolley (Cormiler) }\end{array}$} & $\begin{array}{l}\text { 8. Performing Organ. Report No. } \\
\text { NBSIR } 75-818\end{array}$ \\
\hline \multirow{2}{*}{\multicolumn{3}{|c|}{$\begin{array}{l}\text { 9. PERFORMING ORGANIZATION NAME AND ADDRESS } \\
\text { NATIONAL BUREAU OF STANDARDS, BOUIdER IabS } \\
\text { DEPARTMENT OF COMMERCE } \\
\text { WASHINGTON, D.C. } 20234\end{array}$}} & $\begin{array}{l}\text { 10. Project/Task/Work Unit No. } \\
2769103\end{array}$ \\
\hline & & & 11. Contract/Grant No. \\
\hline \multirow{2}{*}{\multicolumn{3}{|c|}{ 12. Sponsoring Organization Name and Complete Address (Street, City, State, ZIP) }} & $\begin{array}{l}\text { 13. Type of Report \& Period } \\
\text { Covered }\end{array}$ \\
\hline & & & 14. Sponsoring Agency Code \\
\hline
\end{tabular}

15. SUPPLEMENTARY NOTES

16. ABSTRACT (A 200-word or less factual summary of most significant in formation. If document includes a significant bibliography or literature survey, mention it here.)

This bibliography lists the publications of the INSS Electromagnetics Division between June 30, 1974 and June 30, 1975.

17. KEY WORDS (six to twelve entries; alphabetical order; capitalize only the first letter of the first key word unless a proper name; separated by semicolons) Antenna parameters; attenuation; automated measurer.ents; I1 metrology; field strengti; impedance; laser parameters noise; optical electronics; plase; power; pulsed quantities; squids; transmission lines; waveform analysis; waveruides.

18. AVAILABILITY $\bar{X}$ Unlimited

For Official Distribution. Do Not Release to NTIS

Order From Sup. of Doc., U.S. Government Printing Office

Washington, D.C. 20402, SD Cat. No. C13

\begin{tabular}{|l|c|}
\hline $\begin{array}{l}\text { 19. SECURITY CLASS } \\
\text { (THIS REPURT) }\end{array}$ & 21. NO. OF PAGES \\
UNCL ASSIFIED & 28 \\
\hline $\begin{array}{l}\text { 20. SECURITY CLASS } \\
\text { (THIS PAGE) }\end{array}$ & 22. Price \\
UNCLASSIFIED & $\$ 3.75$ \\
\hline
\end{tabular}

Order From National Technical Information Service (NTIS) Springfield, Virginia 22I5I 